\title{
Microsurgical resection of cauda equina schwannoma with nerve root preservation
}

\author{
Paul C. McCormick, M.D., MPH \\ Columbia University College of Physicians and Surgeons, New York, New York
}

The occurrence of motor deficit following resection of an intradural spinal schwannoma is an uncommon but potentially serious complication. This video illustrates the technique of microsurgical resection of an L-4 sensory nerve root schwannoma with preservation of the corresponding functional L-4 motor nerve root.

The video can be found here: http://youtu.be/HrZkGj1JKd4.

(http://thejns.org/doi/abs/10.3171/2014.V3.FOCUS14267)

KeY Words • cauda equina • nerve root • schwannoma • video

Manuscript submitted May 28, 2014.

Accepted July 10, 2014.

Please include this information when citing this paper: DOI: 10.3171/2014.V3.FOCUS14267.

Address correspondence to: Paul C. McCormick, M.D., MPH, 8th

Street, New York, New York 10032. email: pcm6@ columbia.edu. 